2008

\title{
U.S. Immigration Policy: Contract or Human Rights Law?
}

Victor C. Romero

Penn State Law

Follow this and additional works at: http://elibrary.law.psu.edu/fac_works

Part of the Civil Rights and Discrimination Commons, $\underline{\text { Constitutional Law Commons, Human }}$ Rights Law Commons, and the Immigration Law Commons

\section{Recommended Citation}

Victor C. Romero, U.S. Immigration Policy: Contract or Human Rights Law?, 32 Nova L. Rev. 309 (2008).

This Article is brought to you for free and open access by the Faculty Works at Penn State Law eLibrary. It has been accepted for inclusion in Journal Articles by an authorized administrator of Penn State Law eLibrary. For more information, please contact ram6023@psu.edu. 


\title{
UNited States ImMigration POLICY: CONTRACT OR Human Rights LAW?
}

\author{
VICTOR C. ROMERO*
}

All nations distinguish between their citizens and others. In the United States, the primary set of laws for determining these distinctions is found in our immigration policy. The term "immigration law" refers to a rather narrow set of rules covering essentially two aspects of a non-citizen's stay in the United States: first, those rules that govern when that non-citizen may enter, and, second, those that dictate when she must leave. The whole of United States immigration law and policy relates to either of these two topics.

Although it may be tempting to think of immigration law as primarily involving human rights because it regulates the movement of migrants, it is perhaps more accurate to view it as a form of contract law between the United States and the foreigner. The United States grants the non-citizen the privilege to enter the country for some specific purpose and amount of time, and, in exchange, the non-citizen promises to abide by the terms the country sets forth. Should the non-citizen breach her promise, she must leave the United States.

The United States government consists of three branches-the legislature, the executive, and the judiciary - each of which plays a role in determining what the immigration laws mean, or, in keeping with the contract analogy, what responsibilities the state and the non-citizen have under the immigration contract. As the lawmaking body within our federal government, Congress has the responsibility for drafting the terms of the immigration contract between the United States and the non-citizens who seek entry. Like other federal laws, the terms of the contract are then executed and enforced by the President through administrative agencies, such as the Department of Homeland Security, which promulgate specific regulations to enforce the broad terms of Congress's immigration policy. The United States Supreme Court, along with the lower federal courts, is charged with making sure that the terms of the contract are fairly enforced. In sum, Congress establishes the broad terms of the immigration contract, the President creates rules enforcing those terms, and the United States Supreme Court ensures that those terms are fair.

In reviewing our constitutional immigration history, it is clear that the United States Supreme Court has primarily taken a back seat in the development of the law, allowing Congress and the President to shape immigration policy in ways that reinforce the idea that immigration law is essentially a 
contract and not a human rights policy, and that non-citizens are subject to restraints on their presence in the United States in ways that citizens are not. ${ }^{1}$

At first blush, privileging United States citizens over foreigners makes intuitive sense. Any sovereign nation should be able to set terms by which visitors enter and remain on grounds which are inapplicable to those who are already full members of the polity. On the other hand, the history of congressional immigration policy is fraught with racial and ideological discrimination largely unchecked by the courts. ${ }^{2}$ The underlying idea here is that Congress is in the best position to set the terms of a non-citizen's sojourn in America; an unelected federal judiciary should not second-guess the will of the people as embodied in democratically-enacted immigration policy. While perhaps sound in principle, the historical legacy of court deference to the legislature has had profound effects in our current time, as the United States seeks to determine what immigration policy would best suit a nation embroiled in a foreign war and whose citizens live in the shadow of September $11,2001 .^{3}$

Much of the xenophobia that has gripped our post-9/11 world has its roots in the colonial period before the nation's founding. ${ }^{4}$ Whether escaping religious persecution or seeking better economic circumstances, many European arrivals to the New World brought their cultural baggage along with them, as the displaced Native Americans and imported African slaves soon found out. But the conquerors' prejudices also included nativist bigotry, as the Europeans often settled in ethnic enclaves, each group sticking to its own. ${ }^{5}$ It should come as no surprise, for instance, that Germantown, Pennsylvania began as a village of Germans transplanted from the Old World in $1683 .^{6}$ The tendency to prefer things familiar, and to demonize the foreign,

* Associate Dean for Academic Affairs (University Park), Professor of Law, \& Maureen B. Cavanaugh Distinguished Faculty Scholar, Penn State University, The Dickinson School of Law. This essay is an earlier version of a chapter of my forthcoming book tentatively entitled EVERYDAY LAW FOR IMMIGRANTS (Paradigm Publishers, Inc., 2008), see http://www.paradigmpublishers.com. I thank Richard Delgado for useful comments and Dean Birkenkamp and Beth Davis for permission to excerpt the work here; I also thank Dean Phil McConnaughay for his support of my research generally. Most importantly, I thank my family in the Philippines and my wife, Corie, and my children, Ryan, Julia, and Matthew, for their unwavering love and support.

1. Michael J. Wishnie, Introduction: Immigration and Federalism, 58 N.Y.U. ANN. SURV. AM. L. 283, 286 (2002).

2. See generally ROGER Daniels, GuARding THE Golden DOOR: AMERICAN IMMIGRATION POLICY AND IMMIGRANTS SinCE 1882 3-26 (2004).

3. Wishnie, supra note 1 , at 284.

4. DANIELS, supra note 2 , at 6-9.

5. Id. at 7-8.

6. ROGER DANIELS, COMING TO AMERICA 19 (1990). 
found its way into local anti-immigration policies that excluded certain religious groups and social classes, such as the Quakers and Catholics. ${ }^{?}$

After independence in 1776 , Congressional forays into immigration policy were confined largely to naturalization measures, but otherwise foreigners enjoyed an "open door" to the United States for about one hundred years. ${ }^{8}$ This early laissez-faire attitude toward immigration was born less of national largesse than of a lack of clarity as to who should have control over immigration, the thirteen states or the federal government. ${ }^{9}$ Then, as now, while the national government ultimately decided when and how a foreigner became a United States citizen, it was the states that felt the immediate impact of the non-citizen's migration. Because the fledgling nation was growing rapidly, the United States government was less concerned with limiting immigration than were the individual states, which viewed immigration control as but another manifestation of their reserved power. ${ }^{10}$ Thus, in contrast to states' wariness, the first federal legislation passed during this early period was An Act to Encourage Immigration in 1864. ${ }^{11}$

This tension between the federal and state governments over the power to limit foreign migration was understandable given the new Constitution's lack of clarity. For instance, while Article I, Section 8 specifically granted power to Congress "to establish an [sic] uniform Rule of Naturalization" and "to regulate Commerce with foreign [n]ations," nowhere in Article I or elsewhere did the federal government have specific power to pass general immigration laws regulating the flow of foreigners from abroad. ${ }^{12}$ Because the founders understood that the federal government was one of limited power, the states continued to be most interested in regulating immigration, not only because they thought that this was reserved to them under the Constitution,

Whereas one generalizes about migration from Europe, from England, and from Italy going to the New World, to the American Colonies, and to the cities of the northeastern United States, the fact of the matter is that migration often follows more precise patterns, often from a particular region, city, or village in the sending country to specific regions, cities, or even specific city blocks in the receiving nation.

Id. The first major German migration in 1683, for instance, resulted because villagers from Krefeld decided to move en masse to establish what is now Germantown, Pennsylvania. Id. For a more complete account of United States historical immigration legislation briefly described below, see generally DAVID WEISSBRODT \& LAURA DANIELSON, IMMIGRATION LAW AND PROCEDURE IN A NuTSHELl (5th ed. 2005).

7. WEISSBRODT \& DANIELSON, supra note 6 , at 2.

8. See Kleindienst v. Mandel, 408 U.S. 753, 761 (1972).

9. See DANIELS, supra note 2, at 9; WEISSBRODT \& DANIELSON, supra note 6, at 4 .

10. WEISSBRODT \& DANIELSON, supra note 6 , at 4.

11. Edith Abbott, Federal Immigration Policies, 1864-1924, 2 U.J. Bus. 133, 133 (citing Act of July 4, 1864, ch. 246 Stat. 385 (1864)).

12. U.S. CONST. art. I, $\S 8$. The word "migration" appears once in Article I, Section 9, but only in connection to the slave trade. U.S. CoNST. art. I, $\S 9, \mathrm{cl} .1$. 
but also because they were most likely to feel the impact of a large immigrant influx. And so, it is perhaps unsurprising that Founding Father Benjamin Franklin, himself an immigrant, was concerned about the influx of German Catholics into his native Pennsylvania, just as many Californians and Arizonans today are concerned about the large migration of Latin Americans into the desert southwest.

Between 1820 and 1880, large numbers of German and Irish Catholics arrived in the United States to escape the European economic depression of the time, and, in turn, some predominantly Protestant states passed laws in an attempt to stem the tide of Catholic migration. ${ }^{13}$ This nascent anti-immigrant movement proved unsuccessful at the federal level due to the aggregate political strength of the Irish and German migrants nationally.

Over time, this brewing conflict between federal and state power over immigration came to a head. The United States Supreme Court stepped in to resolve this dispute, ruling against the states and paving the way for Congress to begin to craft a uniform immigration policy for the nation. ${ }^{14}$ Following the United States Supreme Court rulings in The Passenger Cases ${ }^{15}$ and Henderson v. Mayor of New York, ${ }^{16}$ finding state immigration laws unconstitutional, Congress enacted the first general federal restrictions on immigration law in 1882, which included a fifty-cent head tax and exclusionary laws based on criminal and economic grounds. ${ }^{17}$ While this first set of restrictions did not single out any particular ethnic group for exclusion, the nativist sentiments that led to state laws against Catholic immigration found expression in a more particular piece of federal legislation that year. ${ }^{18}$

Later in 1882, Congress enacted immigration restrictions reminiscent of the states' recent anti-Catholic pronouncements, when it passed the Chinese Exclusion Act. ${ }^{19}$ First brought in to work on the westward expansion of the railroads, Chinese laborers fell into disfavor once they reached a critical

13. DANIELS, supra note 2, at 9-11.

14. See Henderson v. Mayor of New York, 92 U.S. 259 (1875); The Passenger Cases, 48 U.S. (7 How.) 283 (1844).

15. 48 U.S. (7 How.) 283 (1844).

16. 92 U.S. 259 (1875).

17. Act of Aug. 3, 1882, ch. 376, 22 Stat. 214 (1883). See also Sarah H. Cleveland, Powers Inherent in Sovereignty: Indians, Aliens, Territories, and the Nineteenth Century Origins of Plenary Power over Foreign Affairs, 81 TEX. L. REv. 1, 103-08 (2002).

18. Victor C. Romero, Expanding the Circle of Membership by Reconstructing the "Alien": Lessons from Social Psychology and the "Promise Enforcement" Cases, $32 \mathrm{U}$. MiCH. J.L. REFORM 1, 9 (1999).

19. Chinese Exclusion Act of 1882, ch. 126, 22 Stat. 58 (repealed 1943). 
mass and the work was completed. ${ }^{20}$ Unlike the religious and ideological divide that separated the Anglo-Saxon Protestants from the Irish and German Catholics, the growing distrust of the Chinese appeared more racial and cultural in origin. ${ }^{21}$ Because no large ethnic voting block protected the Chinese as it did the Catholics, Congress handily passed the Chinese Exclusion Act to prevent a further influx. ${ }^{22}$

One such worker adversely affected by the law was Chae Chan Ping. A twelve-year resident of the United States, he had permission from the government to visit China, for which he received a certificate of return for presentation upon his reentry. ${ }^{23}$ At the border, however, federal officials revoked Chae Chan Ping's certificate and excluded him from reentering the United States under the Chinese Exclusion Act. ${ }^{24}$ Before the United States Supreme Court in Chae Chan Ping v. United States, ${ }^{25}$ Chae's lawyers argued that Congress could not unilaterally revoke his permit to briefly travel abroad. ${ }^{26}$ The Supreme Court flatly rejected that argument, holding that as a sovereign nation, the United States has the unilateral prerogative to make immigration policy as it sees fit, and noting that non-citizens enjoy no right to be in the country. ${ }^{27}$ The Court then ruled that Congress had the power to exclude Chae because he was a member of a group, the Chinese, whom Congress had deemed to be undesirable. ${ }^{28}$ Its rhetoric regarding the unassimilable nature of the Chinese and the implication that they presented a threat to the United States even during peacetime, evinces the xenophobia first evident in precolonial restrictions on migration:

If, therefore, the government of the United States, through its legislative department, considers the presence of foreigners of a different race in this country, who will not assimilate with us, to be dangerous to its peace and

20. Kitty Calavita, The Paradoxes of Race, Class, Identity, and "Passing": Enforcing the Chinese Exclusion Acts, 1882-1910, 25 LAW \& SOC. INQUIRY 1, 4 (2000).

21. See id.

22. WeISSBRODT \& DANIELSON, supra note 6, at 5-7.

23. Chae Chan Ping v. United States, 130 U.S. 581, 582 (1889). Hiroshi Motomura sees Chae Chan Ping as supporting the idea that our immigration policy operates like contract law. See Hiroshi Motomura, Americans IN WAITING: THE LOST STORY OF IMMIGRATION AND CITIZENSHIP IN THE UNITED STATES 15 (2006) ("Chae Chan Ping's case is a prime example of the view of immigration that I am calling immigration as contract.").

24. Chae Chan Ping, 130 U.S. at 582.

25. Id. at 581 .

26. See id. at 584 .

27. See id. at 606-07.

28. Id. at 607-09. 
security, their exclusion is not to be stayed because at the time there are no actual hostilities with the nation of which the foreigners are subjects. ${ }^{29}$

Four years later in Fong Yue Ting $v$. United States, ${ }^{30}$ the Court extended its holding in Chae Chan Ping by concluding that, incident to its plenary power over immigration law, Congress also had the power to deport or expel. $^{31}$ Perhaps even more disturbing than the rule the Court announced is that Fong's deportation came about as a result of his failure to come up with a "credible white witness" to testify to the length of his residence in the United States. ${ }^{32}$ While Chinese nationals were ready to testify to Fong's continuous residence in the United States as the statute required, Fong was unable to secure such testimony from a white witness, perhaps owing to barriers created by culture and language, if not by racism. ${ }^{33}$ The Court found the "white witness" requirement to be neither irrational, nor a denial of due process, deferring to Congress's judgment on the desirability of Chinese migration and the terms under which Chinese nationals must leave the United States. ${ }^{34}$ This privileging of the white witness in Fong Yue Ting mirrors the xenophobia of the Chinese people's inability to assimilate in Chae Chan Ping. ${ }^{35}$

While good reasons support the Court's deferral to Congress in both Chae Chan Ping and Fong Yue Ting, these are easily overshadowed by the racism afoot in both opinions. On the one hand, the structure and functions of the Constitution suggest that Congress, and not the Court, should be in charge of formulating immigration law and policy because it is the lawmaking body of the federal government. This exclusive power of Congress over immigration law came to be known as the "plenary power doctrine"- to wit, that as the legislative organ of the federal government, Congress has the sole right to determine what laws govern the entry and exclusion of those persons who are not citizens of the United States. ${ }^{36}$

On the other hand, the very structure of the Constitution requires that the Court stand vigilant in making sure that Congress does not abuse its plenary power and that its immigration policies are fundamentally fair to noncitizens. Put another way, the Court has the responsibility for reviewing

29. Chae Chan Ping, 130 U.S. at 606.

30. 149 U.S. 698 (1893).

31. Id. at 728 .

32. Id. at 729 .

33. Id. at 703-04.

34. Id. at 729-30.

35. Fong Yue Ting, 149 U.S. at 729-30; Chae Chan Ping v. United States, 130 U.S. 581, 595 (1889).

36. Fong Yue Ting, 149 U.S. at 731. 
legislative action when it appears that the terms of Congress's contract with the non-citizen violate a central constitutional truth. In a case decided just a few years before Chae Chan Ping and Fong Yue Ting, the Court held in Yick Wo v. Hopkins ${ }^{37}$ that San Francisco could not discriminate against Chinese nationals by denying them permits to operate laundries solely on the basis of their race. ${ }^{38}$ Invoking the Constitution's Equal Protection Clause, the Court concluded that a local government could not make race a factor in determining how to enforce the terms of a municipal ordinance. ${ }^{39}$ To do so would treat Chinese non-citizens and others unequally under a law that was designed not to limit immigration to the United States, but to regulate the safety of laundries in San Francisco. ${ }^{40}$

In contrast to Yick Wo, the Court in both Chae Chan Ping and Fong Yue Ting failed to place a check on Congress's power over immigration law by allowing it to make race and national origin factors in determining whether these foreign workers could remain in the United States. ${ }^{41}$ In Chae Chan Ping, it was the plaintiff's foreignness alone that made it permissible for Congress to renege on its promise to readmit him into the country, ${ }^{42}$ while in Fong Yue Ting, it was the Chinese man's failure to find a white witness that led to his deportation. ${ }^{43}$

The secret to reconciling these seemingly disparate cases-Yick Wo favoring the non-citizen versus Chae Chan Ping and Fong Yue Ting favoring the government-lies in understanding the separate roles the federal and state governments play with regard to immigration policy. As we saw earlier, the Court in the late nineteenth century struck down state immigration laws, and once Congress started enacting its own restrictive migration policies, the Court affirmatively approved these. ${ }^{44}$ This guidance by the Court made clear that while both the state and federal legislatures may want to re-

37. 118 U.S. 356 (1886). In a forthcoming essay, Jack Chin claims that Yick Wo was actually not too remarkable as an equal protection case, but was rather a property-rights case consistent with existing precedent. Gabriel J. Chin, Abstract, Unexplainable on Grounds of Race: Doubts about Yick Wo (U. of Ariz., Paper No. 07-30, 2007), http://papers.ssrn.com/sol3/papers.cfm?abstract_id=1075563. Specifically, he claims that it narrowly stands for the proposition that treaty obligations to the Chinese trumped the state's ability to regulate against them. Id.

38. Yick Wo, 118 U.S. at 374.

39. Id.

40. Id. at $362-63$.

41. See Chae Chan Ping v. United States, 130 U.S. 581 (1889). See also Fong Yue Ting, 149 U.S. at 698.

42. Chae Chan Ping, 130 U.S. at 609.

43. Fong Yue Ting, 149 U.S. at 729.

44. See id. at 731; Chae Chan Ping, 130 U.S. at 610-11; Yick Wo, 118 U.S. at 374; see also supra notes 11-28 and accompanying text. 
strict immigration, the Constitution has given that power to Congress, not the states. $^{45}$ Even though San Francisco's laundry ordinance in Yick Wo did not purport to restrict immigration, observers saw it as an attempt to discriminate against Chinese nationals, something which the city, as a state municipality, could not do. ${ }^{46}$ Such laws that indirectly seek to influence immigration by directly targeting non-citizens have come to be known as "alienage law," whether passed by the state, local, or federal government. ${ }^{47}$ Chae Chan Ping and Fong Yue Ting make clear that Congress can directly set the terms of a non-citizen's immigration contract on virtually any grounds, even on racial grounds the Court would not condone at the municipal level in Yick Wo. ${ }^{48}$

After the creation of the plenary power doctrine through Chae Chan Ping and its progeny, Congress took full advantage of this new-found strength by passing many laws restricting immigration. These restrictions ranged from the exclusion of the "pauper" and the polygamist, to the expulsion of the Asian and the "anarchist."49 Notable among these was the National Origins Quota system established in 1924, which pegged permissible immigration to two percent of the number of persons from that country as reflected in the census. ${ }^{50}$ While facially neutral, the quota operated as a bar to Asian migration, ${ }^{51}$ following on the heels of the Chinese Exclusion Act of 1882 and the 1917 establishment of an "Asiatic barred zone." 52

The 1950s saw another period of nativistic sentiment, this time highlighting ideology rather than race as a legitimate ground for discriminating against non-citizens. Following World War II and the advent of the Cold War, Congress and the President turned to a stricter enforcement of ideological bases for excluding and deporting non-citizens, supported in their efforts by the United States Supreme Court. ${ }^{53}$ Just as it did in Chae Chan Ping and Fong Yue Ting, the Court would not stand in the way of the federal legisla-

45. See Fong Yue Ting, 149 U.S. at 731; Chae Chan Ping, 130 U.S. at 610-11. See also Yick Wo, 118 U.S. at 374.

46. Yick Wo, 118 U.S. at 363.

47. See Romero, supra note 18 , at 8 .

48. See Yick Wo, 118 U.S. at 367-68.

49. See Act of 1903, ch. 1012, § 39, 32 Stat. 1213, 1222 (amended by Act of Oct. 16, 1918, ch. 186, 40 Stat. 1012 (repealed 1952)); Chinese Exclusion Act of 1882, ch. 126, 22 Stat. 58 (repealed 1943). See also Chae Chan Ping, 130 U.S. at 608.

50. Immigration Act of 1924, ch. 190, $\S 11,43$ Stat. 153, 159.

51. IRA J. KURZBAN, KURZBAN'S IMMIGRATION LAW SOURCEBOOK 3 (7th ed. 2000).

52. See Chinese Exclusion Act ch. 126; Immigration Act of 1917, ch. 29, $\S 2,39$ Stat. 874, 876 (amended 1952).

53. See Shaughnessy v. United States ex rel. Mezei, 345 U.S. 206, 210, 216 (1952). 
ture's and executive's decisions to privilege democracy over communism, despite the negative impact upon longtime residents of the United States. ${ }^{54}$

In Shaughnessy v. United States ex rel. Mezei ${ }^{55}$ for instance, the Court upheld the four year detention of Ignatz Mezei on Ellis Island following his return from visiting his dying mother in Romania. ${ }^{56}$ Because immigration officials were concerned that Mezei, a twenty-five-year non-citizen resident of the United States, had spent nineteen months "behind the Iron Curtain," the Court deferred to Congress's and the executive's judgment that his detention without charge was a national security concern. ${ }^{57}$ It did so without specific proof of why Mezei was a threat to the nation; the Court simply accepted the political branches' representations that he was one. ${ }^{58}$ Like in the Chinese Exclusion Act cases, the Court believed its proper role was to defer to the reasoned judgment of the other two federal branches, even without specific proof that the individual non-citizens-all longtime guests of the nation--had violated the terms of their stay in the United States. ${ }^{59}$

In addition to the more stringent emphasis on ideological concerns, Congress and the Executive continued their promulgation and enforcement of racially discriminatory immigration policies, though this time, a bit more subtly. In 1952, Congress passed the McCarren-Walter Act, a comprehensive immigration bill that forms the framework of modern United States immigration law today, but included within it a more restrictive version of the National Origins Quota system and established a new special racial quota for Asians. ${ }^{60}$ The Attorney General also repatriated 1.3 million Mexicans-and, it turns out, Mexican-Americans-during the infamous "Operation Wetback," designed to combat undocumented migration. ${ }^{61}$

It may be argued that the plenary power doctrine should be divorced from its racist origins because it possesses independent value--the doctrine

54. See id. at 216.

55. Id. at 206.

56. Id. at $208,216$.

57. Id. at $214,216$.

58. See Shaughnessy, 345 U.S. at 214-15.

59. See id. at $214,216$.

60. See Immigration and Nationality Act, Pub. L. No. 414, 66 Stat. 163, 177 (1952).

61. KEVIN R. JoHNSON, THE "HudDLED MASSES" MYTH: IMMIGRATION AND CIVIL RIGHTS 29 (2003). Some commentators have argued that the historical discrimination on race and ideological grounds merely mirrored the domestic discrimination citizens suffered as well. See, e.g., id. at 13; Gabriel J. Chin, Is There a Plenary Power Doctrine? A Tentative Apology and Prediction for Our Strange but Unexceptional Constitutional Immigration Law, 14 GEO. IMMIGR. L.J. 257, 257 (2000). Per this view, minority citizens - whether on account of race, gender, or sexual orientation-received few protections by the United States government; it should be no surprise then that non-citizens in the same groups also suffered accordingly. See Chin, supra, at 257-58. 
properly places immigration law within the political realm, outside the purview of unelected federal judges. As the political climate changes, the laws change through amended legislation, not by judicial fiat. Indeed, several Congressional initiatives have corrected the sins of the past, including the 1965 abolition of the National Origins Quota system ${ }^{62}$ — which has led to a large influx of Asian immigration-and the passing of the Refugee Act of $1980,{ }^{63}$ the beneficiaries of which have been largely from Communist regimes. $^{64}$

But the near total deference afforded the political branches through the plenary power doctrine may come at a high price to human rights. This question of how to balance the role of the federal courts as a check against the executive and the legislature is of particular concern to many non-citizens post 9/11. Moreover, as de facto "first responders," what role do states and local governments play in a regime in which the Constitution confers immigration power exclusively upon the federal government?

While the Court has consistently affirmed the original plenary power doctrine born of the Chinese Exclusion Act cases, it has also developed two other themes in an attempt to carve out a role for itself and the states in the immigration policy debate. First, the Court recognizes it has the authority to tell Congress when it has gone too far in imposing conditions upon the noncitizen that violate her basic rights as an individual. ${ }^{65}$ It has done so subtly, either by requiring Congress and the executive to provide for constitutional due process safeguards, or by reading statutes and regulations broadly so as to protect non-citizens from arbitrary treatment. ${ }^{66}$ Second, the Court has held that states have only a limited role in regulating the activity of noncitizens under so-called "alienage law."67 While states are free to place limits on the activities of non-citizens that go to the heart of state governance, they may not enact legislation that discriminates against non-citizens in their eligibility for public benefits as an alternative to directly preventing them from settling into their state. ${ }^{68}$

Landon v. Plasencia ${ }^{69}$ is one prominent example of the Court requiring the then Immigration and Naturalization Service (INS) to provide a non-

62. See Immigration and Nationality Act Amendments of 1965, Pub. L. No. 89-236, 79 Stat. 911.

63. Refugee Act of 1980, Pub. L. No. 96-212, 94 Stat. 102.

64. See Michael J. Churgin, Mass Exoduses: The Response of the United States, 30 INT'L MigRation REv. (SPECIAL ISSUE) 310, 317 (1996).

65. See Mathews v. Diaz, 426 U.S. 67, 85 (1976).

66. See generally Clark v. Martinez, 543 U.S. 371, 386 (2005).

67. See Mathews, 426 U.S. at 84 .

68. See id. at 84 n.25.

69. 459 U.S. 21 (1982). 
citizen with a hearing in accord with the Constitution's due process clause. ${ }^{70}$ Salvadoran national Maria Plasencia, a lawful permanent resident for five years, had left the United States for a brief, two-day visit to Mexico. ${ }^{71}$ Upon her re-entry, federal authorities charged her with smuggling undocumented persons into the United States knowingly and "for gain."72 An immigration judge summarily excluded Plasencia from entry after an expedited hearing at which she would ordinarily have been entitled to free legal counsel under then existing rules. ${ }^{73}$ Because of her limited English, however, she had unknowingly waived her right to such assistance. ${ }^{74}$ The "for gain" portion of the charge also bespeaks injustice and careless prosecuting. ${ }^{75}$ While the evidence suggested that she provided a ride to undocumented individuals whom she met in Tijuana, it is unclear whether Plasencia knew that they were undocumented and even less clear whether she had received any money for transporting them. ${ }^{76}$ Nonetheless, the immigration judge found her excludable, which would have required her separation from both her United States citizen husband and children. ${ }^{77}$ The United States Supreme Court vacated the immigration judge's order, suggesting that Plasencia may not have been given due process in light of her substantial connections to the United States: "Plasencia's interest here is, without question, a weighty one. She stands to lose the right 'to stay and live and work in this land of freedom.' Further, she may lose the right to rejoin her immediate family, a right that ranks high among the interests of the individual." 78

In reviewing "alienage law" - the law affecting non-citizens in the United States aside and apart from the entry and exit rules of immigration law-courts subject federal legislation to a "rational basis" test that has only occasionally resulted in invalidating discriminatory legislation. ${ }^{79}$ Under such review, the Court will generally defer to the government's reasons for enacting legislation if these appear reasonable. ${ }^{80}$ However, if the Court believes

70. Id. at 32 .

71. Id. at 23 .

72. Id.

73. Id. at $24-25,36$.

74. Landon, 459 U.S. at 36 . These facts are described more fully in Kevin Johnson's description of the case. IMMIGRATION Stories 223-25 (David A. Martin \& Peter H. Schuck eds., 2005).

75. Landon, 459 U.S. at 39-40 (Marshall, J., concurring in part and dissenting in part).

76. See id. at 40 n.5.

77. See id. at 23,34 (majority opinion).

78. Id. at 34 (quoting Bridges v. Wixon, 326 U.S. 135, 154 (1945)) (citation omitted).

79. See Mathews v. Diaz, 426 U.S. 67, 73 (1976).

80. A good example of a deferential application of rational basis review appears in $M a$ thews v. Diaz. Id. at 83. Lawful permanent residents (LPR)-so-called "green card" holders-had challenged federal Medicare rules that only allowed for supplemental insurance 
that the federal government has unfairly singled out non-citizens for unfavorable treatment, it will strike down legislation even under the deferential rational basis standard. ${ }^{81}$

Aside from directly invoking procedural due process protections, as in Landon, or employing a more stringent rational basis review, the Court has also interpreted immigration statutes broadly to protect non-citizens from government overreaching. In Zadvydas $v$. Davis, ${ }^{82}$ the Court ruled that authorities could not hold a lawful permanent resident indefinitely, pending the government's efforts to deport him. ${ }^{83}$ Following a finding that Zadvydas was deportable for having committed certain crimes, the government had sought to remove him, but could find no country willing to accept him; it therefore argued that it could detain Zadvydas indefinitely until it could effect his deportation, citing the 1953 Mezei case discussed earlier. ${ }^{84}$ The government reasoned that if it could hold Mezei, a returning lawful permanent resident indefinitely at Ellis Island on national security grounds, then it could also hold Zadvydas, because his criminal conduct vitiated his right to remain in the United States. ${ }^{85}$ The Court rejected this argument, finding that Congress intended to place a limit of reasonableness on a deportee's length of detention pending deportation. ${ }^{86}$ Concerned that a statute authorizing the indefinite detention of non-citizens would raise serious due process problems, the Court imposed a presumption of unconstitutionality to any period of confinement exceeding six months. ${ }^{87}$

benefits to those who had been in the country for at least five years. Id. at $70 \mathrm{n} .1$. Applying a deferential rational basis review, the Court held that it was reasonable for Congress to condition receipt of these federal benefits on the length of an LPR's stay, noting that those who had been in the United States longer may have stronger ties to the nation. Id. at 83.

81. See Hampton v. Mow Sun Wong, 426 U.S. 88, 116 (1976). Hampton stands as an example of when the rational basis review may be used to strike down laws that irrationally discriminate against non-citizens. See id. Lawful permanent residents challenged United States Civil Service Commission regulations excluding all non-citizens from occupying federal civil service jobs, limiting such occupations to United States "citizens and natives of American Samoa." Id. at 90. Applying what appeared to be a more stringent version of the rational basis test than in Mathews, the Court ruled that the government's desire for administrative convenience did not outweigh lawful non-citizens' rights to be considered on the same footing as United States citizens for such jobs. See id. at 115-16.

82. 533 U.S. 678 (2001).

83. Id. at $689,699-700$.

84. Id. at 684,692 . This consolidated case also involved a second criminal non-citizen, Ma, whom no other country would accept. Id. at 685 .

85. Id. at 692.

86. Zadvydas, 533 U.S. at 699.

87. Id. at 701 . 
In 2005, the Court extended the holding of Zadvydas regarding deportable non-citizens to excludable non-citizens as well, thereby effectively limiting Mezei's reach. ${ }^{88}$ Clark v. Martinez ${ }^{89}$ had its origins in the Mariel boatlift twenty-five years earlier. ${ }^{90}$ Embarking from the port of Mariel, approximately 125,000 Cubans arrived in the United States as refugees in 1980; most of these "Marielitos" had relatives in the United States whom they rejoined, eventually becoming lawful permanent residents. ${ }^{91}$ However, the Immigration and Naturalization Service (INS) had identified about 2000 individuals as being risks to public safety either because they had committed serious crimes or had suffered from severe mental illnesses that rendered them dangerous to others. ${ }^{92}$ Under immigration law, it was as if these persons had never arrived; like Chae Chan Ping and Mezei before them, the Cubans would not be permitted to legally and formally enter the United States because of the danger they posed to the public-in technical parlance, they were "inadmissible." Cuba would not accept them back, but because of the threat they posed to safety, the INS was also unwilling to release them from detention, opting instead to temporarily "parole" them pending their removal. ${ }^{94}$ Unfortunately, many of those released committed crimes, prompting the government to re-detain them. ${ }^{95}$

At issue in Clark v. Martinez was whether Mezei allowed the government to indefinitely detain these otherwise excludable Cubans, or whether the logic of Zadvydas placed reasonable limits on the government's detention power. ${ }^{96}$ The Court chose to extend Zadvydas to cover the inadmissible Cubans, holding that it was Congress's presumptive intent that all non-citizens, regardless of status - whether deportable or inadmissible - should not be detained for more than six months pending their removal. ${ }^{97}$ Undergirding this opinion was the Fifth Amendment's Due Process Clause, which the Court in both Clark and Zadvydas saw as the basis for reading Congress's intent in favor of the non-citizens, thereby limiting the government's power over them. ${ }^{98}$

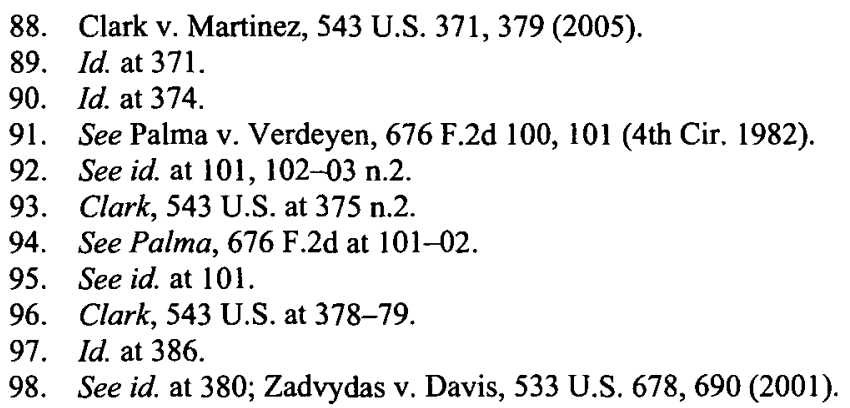


In contrast to the general deference accorded Congress in formulating policies affecting non-citizens, both within and outside the immigration rules, the Court has more stringently reviewed state laws, holding that states have only a limited role in regulating the activity of non-citizens under alienage law. In Graham v. Richardson, ${ }^{99}$ the Court applied a more searching "strict scrutiny" test to root out invidious state discrimination against noncitizens. ${ }^{100}$ In Graham, the Court invalidated state welfare laws, which contained citizenship and durational residency requirements that unfairly discriminated against non-citizens. ${ }^{101}$ The reason for the difference in the Court's treatment of the two sets of law stems from its view of the proper role of the federal and state governments vis-à-vis non-citizens. ${ }^{102}$ Because Congress enjoys plenary power over immigration policy, it makes sense that Congress should also enjoy some leeway in other federal laws it passes that affect non-citizens during their visit. States, on the other hand, have no power to grant United States citizenship under our Constitution, nor do they have a say in who gets to enter and who has to leave. ${ }^{103}$ Immigration law is a federal matter, and so if a state decides that it wants to indirectly influence a non-citizen's residential choices by passing restrictive state laws, the Court will examine those with a keen eye to ensure that some higher, more important governmental objective is present than simply the desire to conserve resources for United States citizens and lawful permanent residents first. ${ }^{104}$

Given that governments often use national origin as a proxy for racial discrimination-think of both the Japanese internment and the post-9/11 profiling of Muslims and Arabs - the Court holds states more accountable than the federal government for laws adversely affecting their non-citizen populations. ${ }^{105}$ The stricter scrutiny applied to state action has led to the invalidation of a host of laws, from citizenship limitations on the ability to

99. 403 U.S. 365 (1971).

100. Id. at 376.

101. Id. The main difference between Graham - a state benefits law case-and Mathews-a federal benefits case-appears to be the degree to which the Court was willing to substitute its judgment for the Legislature's. See generally Mathews v. Diaz, 426 U.S. 67, 8485 (1976). While in Graham, the Court was willing to second-guess the legislature, in $\mathrm{Ma}$ thews, it wasn't. Id. Hence, it is unsurprising that in Sugarman v. Dougall, the Court struck down an anti-non-citizen state civil service rule similar to the federal one in Hampton. 413 U.S. 634, 646-47 (1973).

102. See Graham, 403 U.S. at 376-77.

103. Id. at 382 .

104. See id. at 378-79.

105. See In re Griffiths, 413 U.S. 717, 721-22, 724 (1973). 
practice law ${ }^{106}$ to the ineligibility for financial aid for college based on alienage. ${ }^{107}$

The Court has even protected undocumented immigrant children from state discrimination, applying a slightly less severe standard than strict scrutiny. ${ }^{108}$ In Plyler v. Doe ${ }^{109}$ the Court struck down a Texas law that denied free public education to elementary and secondary school children of undocumented immigrants. ${ }^{110}$ Writing for a 5-to-4 majority, Justice Brennan applied what appeared to be an intermediate level of scrutiny, reasoning that because these innocent children were brought by their parents to this country, denying them the right to an education would impose a grave disability and create a permanent underclass of uneducated children. ${ }^{111}$

If we have learned one thing from this brief tour of the nature and history of United States immigration law and policy, it is that Congress is the main governmental entity responsible for changes in America's contract with non-citizens. While that law may at times appear to be protective of human rights and dignity (in its refugee and amnesty laws, for instance), and at other times draconian and uncaring (in its denial of judicial review or its expedited deportation procedures), one should appreciate it for what it is-a list of rules governing the conditions under which non-citizens may enter and must leave the United States. It is more like a contract than a human rights document, and, in our country, Congress has the near exclusive power to define the terms of that contract.

To see this, we need only review one recent United States Supreme Court pronouncement on the rights of non-citizens under federal immigration law and policy-a decision that reflects the judiciary's continued deference to congressional plenary power. In Fernandez-Vargas $v$. Gonzales, ${ }^{112}$ Mexi-

106. Id. at 724 .

107. Nyquist v. Mauclet, 432 U.S. 1, 2, 12 (1977).

108. Plyler v. Doe, 457 U.S. 202, 220, 230 (1982).

109. Id. at 202.

110. Id. at 230 .

111. Id. at 220, 230. Despite the Court's preference for strict review, in one class of cases the Court has deferred to state alienage laws, sometimes called the "public function" exception. See, e.g., Michael Scaperlanda, Partial Membership: Aliens and the Constitutional Community, 81 IOWA L. REV. 707, 736-37 (1996) (describing the "public function" exception). In Bernal v. Fainter, the Court refused to apply strict scrutiny to state alienage classifications "that exclude [non-citizens] from positions intimately related to the process of democratic self-government." 467 U.S. 216, 220 (1984). Hence, in Foley v. Connelie, the Court upheld a New York state law limiting police officer jobs to United States citizens only, reasoning that police are vested with a great deal of discretionary power to maintain law and order-power that, in the state's view, should not be given to non-citizens over citizens. 435 U.S. 291, 298-300 (1978).

112. 126 S. Ct. 2422 (2006). 
can national, Humberto Fernandez-Vargas, first entered the United States in the $1970 \mathrm{~s}$ and was deported for immigration violations several times, but each time he returned illegally to the United States. ${ }^{113}$ His final illegal reentry occurred in 1982, and, for approximately twenty years thereafter, he remained undetected. ${ }^{114}$ His life, however, had taken a turn for the better when he started his own trucking business in Utah, bore a United States citizen son and, in 2001, married the son's mother, his longtime girlfriend, who is also a United States citizen. ${ }^{115}$ When his wife petitioned for his adjustment to LPR status in 2001, the federal government reinstated his 1981 deportation order, denied his application for status adjustment, and deported him to Mexico in 2004. ${ }^{116}$

The issue before the United States Supreme Court was whether the government acted lawfully in resurrecting his now twenty-year-old deportation order pursuant to a federal law that had not been enacted until many years after he had returned to the United States and became a productive member of the community. ${ }^{117}$ In an 8-to-1 decision, the Court interpreted the 1996 law, the Illegal Immigration Reform and Immigrant Responsibility Act, in the government's favor, upholding their reinstatement of the deportation order and his subsequent removal to Mexico. ${ }^{118}$ One might argue that Fernandez-Vargas should not have benefited from his ability to evade the authorities for twenty years; yet, one can easily imagine a judge weighing the equities in this case of a reformed man whose deportation would have devastating consequences for his U.S. citizen child and spouse.

Fernandez-Vargas stands as but the latest in a string of United States Supreme Court cases that underscore the plenary power of Congress over immigration matters, and lends support to the idea that immigration law is more like contract law than human rights law. ${ }^{119}$ Fernandez-Vargas violated the terms of his contract with the United States and was held responsible for his breach; a human rights version of immigration law might have insisted on an impartial arbiter's review of the government's interest in maintaining order, balanced against the non-citizen's reformation. ${ }^{120}$

We have also learned that states have less of a role to play in enforcing or enacting immigration law than does the federal government, although we

113. Id. at 2427.

114. Id.

115. Id.

116. Id.

117. Fernandez-Vargas, $126 \mathrm{~S} . \mathrm{Ct}$ at 2425.

118. Id.

119. See id. at 2422-34.

120. Id. at 2233-34. 
are likely to see more state and local governments seek to find ways to address immigration issues. The reality is that state and local authorities have exhibited growing frustration with the federal government's response to immigration issues, especially with respect to the undocumented.

At an estimated twelve million and counting, ${ }^{121}$ some believe the undocumented have a significant impact in a handful of states and localities, and among the poor and lower classes; in terms of competition for jobs, many have become disillusioned by the perennial underfunding of immigration initiatives and the perceived lax federal approach to immigration enforcement. Yet, others acknowledge that the undocumented form the backbone of a significant number of industries, from farming to construction to textiles, so that the mass deportation of all undocumented persons, even if feasible, would severely damage these businesses and the national economy.

It will be interesting to see whether state and local governments will gain a greater ability to enforce immigration laws in the future. ${ }^{122}$ As states' roles in immigration enforcement increase and the federal government's role correspondingly wanes, scholars and pundits alike will pay close attention to the United States Supreme Court's response to this paradigm shift. Whether the Court will hold on to its traditional skepticism of state actions against non-citizens or begin to defer to such initiatives as emanating from valid Congressional mandates, only time will tell.

121. Muzaffar A. Chishti, Enforcing Immigration Rules: Making the Right Choices, 10 N.Y.U. J. LEGIS. \& PUB. POL'Y 451, 451 (2006-2007).

122. For a collection of thoughtful essays on this issue, see Symposium, Migration Regulation Goes Local: The Role of States in U.S. Immigration Policy, 58 N.Y.U. ANN. SURV. AM. L. 283 (2002), especially Wishnie, supra note 1. 
